\title{
HUBUNGAN KUALITAS PELAYANAN TERHADAP KEPUASAN MAHASISWA DAN LOYALITAS MAHASISWA DITINJAU DARI MODEL PEMBELAJARAN DI AKADEMI FARMASI SURABAYA
}

\author{
Abd. Syakur \\ Magister Administrasi Publik, Universitas Tribhuwana Tunggadewi \\ Jl. Telaga Warna Blok C, Tlogomas, Kec. Lowokwaru, Kota Malang. \\ Email: syakurabdmpd@gmail.com
}

\begin{abstract}
Higher Education as an institution of education service providers are required to provide services that can create maximum satisfaction to the community of its services users, which in turn will be able to encourage the progress of the Higher Education. The research was conducted at Akademi Farmasi Surabaya. The research used responder students, staff and lecturers, chosen randomly. Or also using 30 questions consisting of data analysis process used by the researcher is using multiple linear regression test analysis obtained from the relationship between service quality and student satisfaction as service user to student loyalty. The result showed that for service quality variables obtained the value of $t$ arithmetic of 2.454 with a value of p-value of 0.016, that is a positive influence and significant quality of service to student loyalty. While The results for student satisfaction variables then obtained t count value of 4.901 with a p-value of 0.000 , that is a positive influence and significant student satisfaction on student loyalty.
\end{abstract}

Keywords: Service Quality, Satisfaction and Student's Loyalty.

\begin{abstract}
Abstrak: Perguruan Tinggi sebagai suatu lembaga penyedia jasa pendidikan dituntut dapat memberikan pelayanan yang mampu menciptakan kepuasan maksimal kepada masyarakat pengguna jasanya, yang pada gilirannya justru akan mampu mendorong kemajuan Perguruan Tinggi tersebut. Penelitian dilaksanakan di Institusi Akademi Farmasi Surabaya. Penelitian menggunakan responden mahasiswa, staff, dan dosen, yang diambil secara acak. Ukuran dari penilian yaitu 30 pertanyaan yang terdiri dari Proses analisis data yang digunakan oleh peneliti, yaitu menggunakan analisis uji regresi linear berganda yang diperoleh dari hasil hubungan antara kualitas pelayanan dan kepuasan mahasiswa sebagai pengguna jasa pelayanan terhadap loyalitas mahasiswa. Hasil penelitian menunjukan bahwa untuk variabel kualitas pelayanan diperoleh nilai $t$ hitung sebesar 2,454 dengan nilai pvalue sebesar 0,016, yaitu terdapat pengaruh positif dan signifikan kualitas pelayanan terhadap loyalitas mahasiswa. Sedangkan hasil penelitian untuk variabel kepuasan mahasiswa diperoleh nilai $t$ hitung sebesar 4,901 dengan nilai p-value sebesar 0,000, yaitu terdapat pengaruh positif dan signifikan kepuasan mahasiswa terhadap loyalitas mahasiswa.
\end{abstract}

Kata Kunci: Kualitas Pelayanan, Kepuasan dan Loyalitas Mahasiswa.

\section{PENDAHULUAN}

Kualitas layanan merupakan tuntutan terhadap perguruan tinggi dewasa ini bukan hanya sebatas kemampuan untuk menghasilkan lulusan yang diukur secara akademik, melainkan keseluruhan program dan lembaga-lembaga perguruan tinggi harus mampu 


\section{REFORMASI}

ISSN 2088-7469 (Paper) ISSN 2407-6864 (Online)

Volume 8 Nomor 2 (2018)

membuktikan kualitas yang tinggi yang didukung oleh akuntabilitas yang ada. Bukti prestasi, penilaian, sertifikasi kualitas, keberhasilan alumni dalam mendapatkan pekerjaan yang sesuai dengan bidang ilmunya, serta hasil evaluasi juga dibutuhkan untuk memperoleh pengakuan dari masyarakat.

Pada sisi yang lain peranan pendidikan dalam kehidupan sangatlah penting. Pendidikan menjadi kebutuhan bagi setiap manusia, sehingga manusia berusaha untuk mendapatkan pendidikan yang setinggi-tingginya sebagai bekal untuk bersaing di dunia kerja. Menurut Undang-Undang No. 20 Tahun 2003 tentang sistem Pendidikan Nasional (www.inherent-dikti.net), Pendidikan adalah usaha sadar dan terencana untuk mewujudkan suasana belajar dan proses pembelajaran agar peserta didik secara aktif mengembangkan potensi dirinya untuk memiliki kekuatan spiritual keagamaan, pengendalian diri, kepribadian, kecerdasan, akhlak mulia, serta keterampilan yang diperlukan dirinya, masyarakat, bangsa dan negara. Dengan pentingnya peranan pendidikan, maka dalam Undang-Undang Dasar 1945 diamanatkan setiap warga negara berhak mendapatkan pendidikan, pengajaran dan pemerintah berusaha untuk menyelenggarakan suatu sistem pendidikan nasional yang pelaksanaannya diatur dalam undang-undang.

Upaya memenuhi keinginan mahasiswa dan calon mahasiswa merupakan kunci sukses memenangkan persaingan Panca Winahyuningsih (2012) Tindakan terbaik yang perlu dilakukan oleh lembaga pendidikan tinggi adalah menggunakan umpan balik dari mahasiswa atau calon mahasiswa untuk mengendalikan perubahan organisasional Bergin(1997). Kesesuaian antara keinginan atau persepsi konsumen (customer voice) dan kehendak organisasi pengelola perguruan tinggi (company voice) merupakan syarat penting keberhasilan proses pendidikan tinggi (Muafi dan Yuni Siswanti, 2007).

Menurut Low dalam Gold (2001) karena mahasiswa adalah pelanggan utama perguruan tinggi, sudah seharusnya pelayanan pendidikan tinggi harus berorientasi kepada mahasiswa.Aliffudin (2012) mengingatkan bahwa pelayanan pendidikan memang merupakan hak mahasiswa yang wajib dipenuhi perguruan tinggi sebagai penyedia jasa.Oleh karena itu, menurut Aliffudin, kurang tepat apabila memaknai konsep pelayanan pendidikan hanya dalam spektrum kompetisi antar perguruan tinggi.

Kepuasan mahasiswa berkait erat dengan kesesuaian antara harapan dan kenyataan dari kualitas pelayanan pendidikan yang didapat dari Akademi Farmasi Surabaya.Apabila Akademi Farmasi Surabaya memperlakukan mahasiswa sebagai pelanggan dengan mengevaluasi kesenjangan antara harapan dan kenyataan yang dirasakan mahasiswa terhadap kualitas pelayanan pendidikan, maka Akademi Farmasi Surabaya dapat menyiapkan rencana strategis yang tepat untuk meningkatkan kualitasnya. Evaluasi kepuasan mahasiswa ini dapat digunakan untuk mengetahui faktor-faktor kualitas pelayanan pendidikan yang perlu diperbaiki, dipertahankan, bahkan dikurangi akan mengakibatkan kesalahan alokasi sumber daya seperti dana, tenaga kerja, dan waktu. Kesalahan alokasi sumber daya menyebabkan upaya peningkatan mutu menjadi tidak efektif dan mengurangi kepuasan mahasiswa.

Untuk menelaah kepuasan mahasiswa terkait kualitas pelayanan Akademi Farmasi Surabaya, diperlukan instrumen pengukuran yang tepat.Karena selama beberapa tahun, para peneliti akademis telah mencoba mengukur kualitas jasa dalam perguruan tinggi dengan skala satu dimensi. Hal ini tidak sesuai dengan karakteristik multi-dimensi dari kualitas jasa Tjiptono (2014) setiap tindakan atau perbuatan yang dapat ditawarkan oleh suatu pihak 


\section{REFORMASI}

ISSN 2088-7469 (Paper) ISSN 2407-6864 (Online)

Volume 8 Nomor 2 (2018)

kepada pihak lain yang pada dasarnya bersifat intangible (tidak berwujud fisik) dan tidak menghasilkan kepemilikan sesuatu.

Perkembangan, perumusan menemukan bahwa kualitas layanan dibagi menjadi lima dimensi. Kualitas layanan yang ada dapat dirangkum menjadi lima dimensi "TERRA", yaitu.

1. Tangibles (Bukti Fisik), meliputi fasilitas fisik, perlangkapan, pegawai dan sarana

2. Empathy (Kemampupahaman), meliputi kemudahan dalam melakukan hubungan komunikasi yang baik, perhatian pribadi dan kemampuan memahami kebutuhan para pelanggan yaitu mahasiswa.

3. Responsiveness (Daya Tanggap), yaitu keinginan perusahaan/Perguruan tinggi melalui karyawannya untuk membantu para pelanggan/mahasiswa dan memberikan pelayanan dengan tanggap.

4. Reliability (Keandalan), yaitu perusahaan dalam memberikan pelayanan karyawannya yang dijanjikan dengan segera, akurat dan memuaskan.

5. Assurance (Jaminan), meliputi kemampuan, kesopanan, dan sifat dapat dipercaya yang dimiliki oleh para karyawan, bebas dari bahaya risiko atau keraguraguan.

Adapun tujuan penelitian ini, maka dipandang penting untuk dikaji berkenaan dengan kepuasan mahasiswa pada Akademi Farmasi Surabaya yang ada di Surabaya yang tidak dapat diabaikan dengan faktor-faktor yang mempengaruhinya, yaitu Kepuasan Mahasiswa, Kualitas Pelayanan, dan Loyalitas Mahasiswa pada Akademi Farmasi Surabaya.

\section{METODE PENELITIAN}

Penelitian memiliki tujuan mendeskripsikan hubungan kualitas pelayanan terhadap kepuasan mahasiswa dan loyalitas mahasiswa ditinjau dari model pembelajaran di Akademi Farmasi Surabaya. Penelitian ini dilakukan dengan menggunakan pendekatan kuantitatif melalui rancangan korelasional. Desain penelitian hubungan kualitas pelayanan terhadap kepuasan mahasiswa dan loyalitas mahasiswa ditinjau dari model pembelajaran di Akademi Farmasi Surabaya ini dapat digambarkan sebagai berikut.

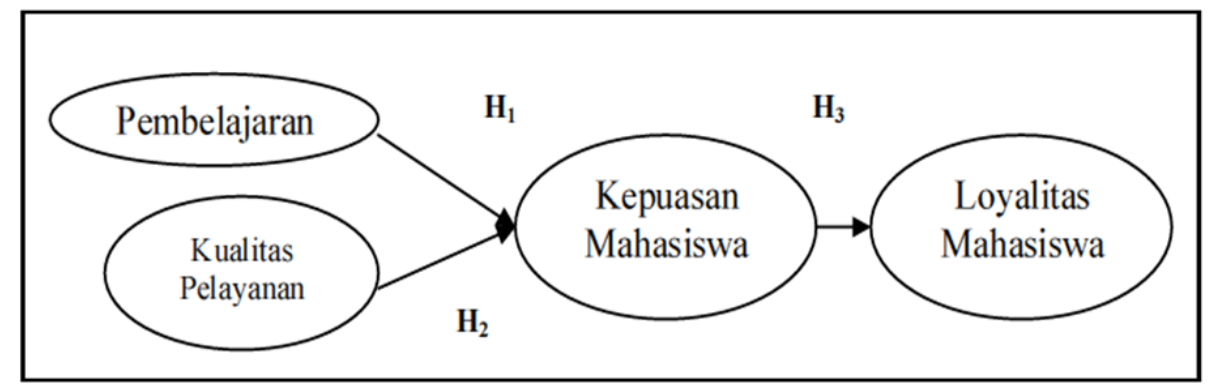

Pada penelitian ini terdapat empat variabel yang akan diukur, yaitu (1) Variabel Kualitas Pelayanan, indikator yang digunakan adalah lokasi kampus, tempat parkir yang luas, kelengkapan buku di perpustakaan, ketersediaan jumlah ruang kuliah yang memadai, dan kenyamanan ruang kuliah; (2) Variabel Kepuasan Mahasiswa, indikator yang digunakan adalah sistem layanan yang baik, kemudahan dan kecepatan memperoleh informasi, biaya yang tidak terlalu mahal, dan lulus tepat waktu; (3)Variabel Loyalitas Mahasiswa, indikator yang digunakan adalah tidak berpindahnya mahasiswa ke universitas 


\section{REFORMASI}

ISSN 2088-7469 (Paper) ISSN 2407-6864 (Online)

Volume 8 Nomor 2 (2018)

lain, rekomendasi, dan positive word of mouth (WOM); dan (4) Variabel Model Pembelajaran, indikator yang digunakan adalah pengetahuan, antusiasme, media belajar (LCD, Slide, OHP), komunikasi, dan bimbingan kesulitan belajar mahasiswa. Setelah itu, membuat draft pernyataaan butir, kefavorabelan pernyataan butir, dan dikhiri dengan pernyataan butir.

Penelitian hubungan kualitas pelayanan terhadap kepuasan mahasiswa dan loyalitas mahasiswa di tinjau dari model pembelajaran di Akademi Farmasi Surabaya, yaitu apabila layanan akademik yang dilaksanakan sesuai dengan harapan dan keinginan mahasiswa, maka kepuasan, loyalitas mahasiswa akan tercapai Pengujian Hipotesis kepuasan dan loyalitas mahasiswa. Penelitian ini dilaksanakan di Institusi Akademi Farmasi Surabaya yang terletak di jalan Ketintang Madya No.81 Surabaya, Waktu pelaksanaan telah di laksanakan pada bulan Januari dan Februari 2018. Jumlah mahasiswa Akademi Farmasi Surabaya mulai tahun akademik 2015/2016 sampai dengan tahun akademik 2017/2018, yaitu sejumlah 1052 mahasiswa, maka sampel yang diambil ditetapkan sejumlah 100 mahasiswa. Responden diminta untuk memberi jawaban yang berupa kuesioner dalam bentuk skala 1-5 dengan kategori jawaban sangat tidak setuju (STS) sampai dengan sangat setuju (SS). Instrumen yang digunakan untuk mengukur $\mathrm{X}$, yaitu variabel kualitas pelayanan, maupun variabel Y, yaitu variabel kepuasan mahasiswa dan mahasiswi, berupa kuesioner (quisioner). Uji coba dilakukan pada 30 mahasiswa, diluar yang dijadikan sampel penelitian.

\section{HASIL DAN PEMBAHASAN \\ Deskripsi Hasil Penelitian}

Proses analisis data yang digunakan oleh peneliti, yaitu menggunakan analisis uji regresi linear berganda yang diperoleh dari hasil hubungan antara kualitas pelayanan dan kepuasan mahasiswa sebagai pengguna jasa pelayanan terhadap loyalitas mahasiswa.

\section{Kualitas Pelayanan}

Kualitas pelayanan meliputi beberapa dimensi, diantaranya adalah bukti fisik, keandalan, ketanggapan, kompetensi, kedisiplinan, dan empati. Penilaian bukti fisik dapat diketahui sebagai berikut :

1. Bukti fisik ruang kuliah yang bersih, rapi, dan nyaman yang dirasakan oleh mahasiswa, yaitu menunjukkan paling dominan kategori setuju sebesar 67\%.

2. Fasilitas dan prasarana (faxmile, kantin, dan tempat ibadah) yang dirasakan oleh mahasiswa, yaitu menunjukkan paling dominan kategori setuju sebesar $64 \%$.

3. Kelengkapan dan kecanggihan peralatan perkuliahan dan sistem akademik yang dirasakan oleh mahasiswa, yaitu menunjukkan paling dominan kategori setuju sebesar $65 \%$.

4. Penataan interior, eksterior, dan kelengkapan laboratorium farmasi yang dirasakan oleh mahasiswa, yaitu menunjukkan kategori setuju dan kurang setuju masing-masing sebesar $42 \%$.

5. Kerapian dan kebersihan penampilan para staf dan dosen serta menjadi contoh dalam bersikap dan berperilaku yang dirasakan oleh mahasiswa, yaitu menunjukkan paling dominan pada kategori setuju sebesar 55\%. 


\section{REFORMASI}

ISSN 2088-7469 (Paper) ISSN 2407-6864 (Online)

Volume 8 Nomor 2 (2018)

Penilaian keandalan dapat diketahui sebagai berikut :

1. Prosedur pelayanan akademik yang mudah, jelas, dan tidak berbelit-belit yang dirasakan oleh mahasiswa, yaitu menunjukkan paling dominan pada kategori setuju sebesar $60 \%$.

2. Kemampuan informasi kegiatan akademik yang konsisten yang dirasakan oleh mahasiswa, yaitu menunjukkan paling dominan pada kategori setuju sebesar 56\%.

3. Pelayanan akademik yang sopan dan ramah yang dirasakan oleh mahasiswa yaitu menunjukkan paling dominan pada kategori setuju sebesar $53 \%$.

4. Adil dalam memperlakukan mahasiswa yang dirasakan oleh responden, yaitu menunjukkan paling dominan pada kategori setuju sebesar 59\%.

Penilaian daya tanggap dapat detahui sebagai berikut :

1. Kemampuan dosen dan staf untuk cepat dan tanggap dalam melayani kebutuhan mahasiswa (konsultasi KTI, KHS, KRS, dan pendaftaran maba) yang dirasakan oleh responden, yaitu menunjukkan paling dominan pada kategori setuju sebesar $46 \%$.

2. Akademik selalu memberikan informasi kemahasiswaan yang akurat (jadwal perkuliahan dan registrasi) yang dirasakan oleh responden, yaitu menunjukkan paling dominan pada kategori setuju sebesar 54\%.

3. Akademik memberi tahu kepada mahasiswa apabila dosen berhalangan hadir yang dirasakan oleh responden, yaitu menunjukkan paling dominan pada kategori setuju sebesar $59 \%$.

Penilaian kompetensi dapat diketahui sebagai berikut :

1. Kesiapan dosen dalam memberikan kuliah (SAP/Silabus, buku referensi, power point, dll) yang dirasakan oleh responden, yaitu menunjukkan sebagian besar pada kategori setuju sebesar $60 \%$.

2. Kejelasan penyampaian materi dan jawaban terhadap pertanyaan di kelas yang dirasakan oleh responden, yaitu menunjukkan paling dominan pada kategori setuju sebesar $46 \%$.

3. Memberikan materi dengan media dan metode yang bervariasi serta kaya akan inovasi yang dirasakan oleh responden, yaitu menunjukkan paling dominan pada kategori setuju sebesar $49 \%$.

4. Kemampuan dan kesiapan menjelaskan pada praktik laboratorium yang dirasakan oleh responden yaitu menunjukkan paling dominan pada kategori setuju sebesar $54 \%$.

Penilaian kedisiplinan dapat diketahui sebagai berikut :

1. Dosen memberikan perkuliahan tepat pada waktunya yang dirasakan oleh responden, yaitu menunjukkan paling dominan pada kategori setuju sebesar 56\%.

2. Dosen mengadakan kuliah tambahan apabila belum mencukupi yang dirasakan oleh responden, yaitu menunjukkan paling dominan pada kategori setuju dan kurang setuju masing-masing sebesar $43 \%$. 


\section{REFORMASI}

ISSN 2088-7469 (Paper) ISSN 2407-6864 (Online)

Volume 8 Nomor 2 (2018)

3. Dosen mengumumkan hasil UTS dan UAS kepada mahasiswa tepat pada waktunya yang dirasakan oleh responden, yaitu menunjukkan paling dominan pada kategori setuju sebesar $50 \%$.

4. Peraturan UTS dan UAS yang diberlakukan yang dirasakan oleh responden, yaitu menunjukkan paling dominan pada kategori sangat setuju dan setuju masingmasing sebesar $45 \%$ dan $44 \%$.

Penilaian empati dapat diketahui sebagai berikut :

1. Dosen dan staf selalu memberikan perhatian kepada mahasiswa yang kurang dalam akademiknya yang dirasakan oleh responden, yaitu menunjukkan paling dominan pada kategori setuju sebesar $49 \%$.

2. Dosen PA memberikan bimbingan akademik dan arahan pada setiap mahasiswa yang dirasakan oleh responden, yaitu menunjukkan paling dominan pada kategori setuju sebesar $42 \%$.

3. Para dosen dan staf berkomunikasi secara baik dengan bahasa yang mudah dimengerti oleh setiap mahasiswa yang dirasakan oleh responden, yaitu menunjukkan paling dominan pada kategori setuju sebesar $49 \%$.

4. Institusi memberikan pelayanan kepada mahasiswa tanpa memandang status sosial dll. yang dirasakan oleh responden, yaitu menunjukkan paling dominan pada kategori setuju sebesar $49 \%$.

5. Fleksibel dalam aturan pembayaran biaya studi yang dirasakan oleh responden, yaitu menunjukkan paling dominan pada kategori setuju sebesar $54 \%$.

\section{Kepuasan Mahasiswa}

Kepuasan konsumen (mahasiswa) merupakan keputusan evaluatif pasca konsumsi berkenaan dengan suatu produk atau jasa khusus konsumen (mahasiswa) yang dapat diketahui sebagai berikut :

1. Responden merasa puas dengan kualitas pelayanan yang diberikan oleh institusi Akademi Farmasi Surabaya, yaitu menunjukkan paling dominan pada kategori setuju sebesar $55 \%$.

2. Mahasiswa merasa sesuai dan cocok dengan keputusannya dalam melakukan studi di Akademi Farmasi Surabaya, yaitu menunjukkan paling dominan pada kategori setuju sebesar $44 \%$.

3. Mahasiswa merasa puas dengan penjelasan materi mata kuliah di Akademi Farmasi Surabaya, yaitu menunjukkan paling dominan pada kategori setuju sebesar $52 \%$.

\section{Loyalitas Mahasiswa}

Loyalitas mahasiswa secara umum dapat didefinisikan sebagai suatu perilaku pembelian pengulangan yang telah menjadi kebiasaan, yang mana telah ada keterkaitan dan keterlibatan tinggi pada pilihan konsuman terhadap obyek tertentu, dan bercirikan dengan ketiadaan pencarian informasi eksternal dan evaluasi alternatif yang dapat diketahui sebagai berikut :

1. Mahasiswa akan memberikan informasi/rekomendasi kepada teman, saudara, siswi SMU, SMK, SMKF yang berminat mendaftar dan melanjutkan kuliah di 


\section{REFORMASI}

ISSN 2088-7469 (Paper) ISSN 2407-6864 (Online)

Volume 8 Nomor 2 (2018)

Akademi Farmasi Surabaya, yaitu menunjukkan paling dominan pada kategori setuju sebesar $51 \%$.

2. Mahasiswa merasa memiliki kompetensi yang lebih selama studi di Akademi Farmasi Surabaya, yaitu menunjukkan paling dominan pada kategori setuju sebesar $57 \%$.

3. Mahasiswa memiliki kesan khusus dan cinta almamater selama studi di Akademi Farmasi Surabaya, yaitu menunjukkan paling dominan pada kategori setuju sebesar $53 \%$.

\section{Uji Kualitas Data}

\section{Uji Validitas}

Uji validitas variabel kualitas pelayanan diketahui bahwa semua nilai p-value < 0,05 untuk masing-masing item pernyataan. Ini berarti bahwa data yang diperoleh dari item-item pernyataan kuesioner yang digunakan untuk mengukur variabel kualitas pelayanan dalam model adalah valid.Sedangkan untuk variabel kepuasan mahasiswa dan loyalitas mahasiswa diketahui bahwa semua nilai p-value $<0,05$ untuk masing-masing item pernyataan. Ini berarti bahwa data yang diperoleh dari item-item pernyataan kuesioner yang digunakan untuk mengukur variabel kepuasan mahasiswa dan loyalitas mahasiswa dalam model adalah valid.

\section{Uji Reliabilitas}

Pengujian reliabilitas dilakukan dengan bantuan program SPSS untuk masingmasing variabel, yaitu kualitas pelayanan $\left(\mathrm{X}_{1}\right)$, kepuasan mahasiswa $\left(\mathrm{X}_{2}\right)$, dan loyalitas mahasiswa (Y), dapat disimpulkan bahwa semua variabel adalah reliabel karena nilai cronbach's alpha lebih dari 0,60. Selanjutnya untuk variabel kepuasan mahasiswa dan loyalitas mahasiswadapat disimpulkan bahwa semua variabel adalah reliabel karena nilai cronbach's alpha lebih dari 0,60.

\section{Interpretasi Data}

\section{Analisis Regresi Linear Ganda}

\section{Konstanta $\left(\boldsymbol{\beta}_{0}\right)$}

Nilai konstanta $\left(\beta_{0}\right)$ sebesar 4,414 menunjukkan bahwa apabila variabel kualitas pelayanan $\left(\mathrm{X}_{1}\right)$ dan kepuasan mahasiswa $\left(\mathrm{X}_{2}\right)$ sama dengan nol atau konstan maka nilai loyalitas mahasiswa (Y) sebesar 4,414 satuan.

\section{Konstanta $\left(\beta_{1}\right)$ untuk variabel kualitas pelayanan $\left(\mathbf{X}_{1}\right)$}

Besarnya nilai koefisien regresi $\left(\beta_{1}\right)$ sebesar 0,034 . Nilai $\beta_{1}$ yang positif menunjukkan adanya hubungan yang searah antara loyalitas mahasiswa (Y) dengan kualitas pelayanan $\left(\mathrm{X}_{1}\right)$ yang artinya jika kualitas pelayanan $\left(\mathrm{X}_{1}\right)$ naik sebesar satu satuan maka besarnya loyalitas mahasiswa (Y) akan naik sebesar 0,034 satuan, dengan asumsi bahwa variabel independen lainnya bersifat konstan.

\section{Konstanta $\left(\boldsymbol{\beta}_{2}\right)$ untuk variabel kepuasan mahasiswa $\left(\mathbf{X}_{\mathbf{2}}\right)$}

Besarnya nilai koefisien regresi $\left(\beta_{2}\right)$ sebesar 0,394 . Nilai $\beta_{2}$ yang positif menunjukkan adanya hubungan yang searah antara loyalitas mahasiswa (Y) dengan 


\section{REFORMASI}

ISSN 2088-7469 (Paper) ISSN 2407-6864 (Online)

Volume 8 Nomor 2 (2018)

kepuasan mahasiswa $\left(\mathrm{X}_{2}\right)$ yang artinya jika kepuasan mahasiswa $\left(\mathrm{X}_{2}\right)$ naik sebesar satu satuan maka besarnya loyalitas mahasiswa (Y) akan naik sebesar 0,394 satuan, denganasumsi bahwa variabel independen lainnya bersifat konstan.

\section{Uji Hipotesis}

\section{Hasil Analisis Uji Kesesuaian Model (Uji F)}

Hasil analisis hubungan kesesuaian model diperoleh keputusan bahwa Tolak $\mathrm{H}_{0}$ yang berarti bahwa ada pengaruh signifikan antara variabel independen dengan variabel dependen. Karena nilai p-value $<\alpha(0,000<0,05)$. Hasil ini berarti model regresi yang dihasilkan pada penelitian ini cocok untuk menguji kualitas pelayanan dan kepuasan mahasiswa terhadap loyalitas mahasiswa.

Hasil koefisien determinasi sebesar 0,300. Hal ini menunjukkan bahwa perubahan yang terjadi pada variabel loyalitas mahasiswa $(\mathrm{Y})$ sebesar $30 \%$ dipengaruhi oleh variabel kualitas pelayanan $\left(\mathrm{X}_{1}\right)$ dan kepuasan mahasiswa $\left(\mathrm{X}_{2}\right)$, sedangkan sisanya $70 \%$ dikarenakan oleh faktor lain yang tidak termasuk dalam model.

Sumbangan efektif dari masing-masing variabel independen adalah kualitas pelayanan sebesar 0,078 (7,8\%) dan kepuasan mahasiswa sebesar 0,222 (22,2\%). Maka dapat disimpulkan bahwa variabel yang paling dominan yang berpengaruh terhadap loyalitas mahasiswa di Akademi Farmasi Surabaya adalah kepuasan mahasiswa dengan sumbangan terbesar sebesar $22,2 \%$ atau $74 \%$ dari seluruh besarnya pengaruh.

\section{Uji Parsial (Uji t)}

\section{Pengaruh kualitas pelayanan $\left(\mathrm{X}_{1}\right)$ secara parsial terhadap loyalitas mahasiswa $(\mathrm{Y})$}

Berdasarkan hasil analisis untuk variabel kualitas pelayanan maka diperoleh nilai t hitung sebesar 2,454 dengan nilai p-value sebesar 0,016. Karena nilai p-value kurang dari 0,05, maka tolak $\mathrm{H}_{0}$. Jadi, dapat disimpulkan bahwa terdapat pengaruh positif dan signifikan kualitas pelayanan terhadap loyalitas mahasiswa.

\section{Pengaruh kepuasan mahasiswa $\left(\mathbf{X}_{2}\right)$ secara parsial terhadap loyalitas mahasiswa $(\mathbf{Y})$}

Berdasarkan hasil analisis untuk variabel kepuasan mahasiswa maka diperoleh nilai t hitung sebesar 4,901 dengan nilai p-value sebesar 0,000. Karena nilai p-value kurang dari 0,05 , maka tolak $\mathrm{H}_{0}$. Jadi, dapat disimpulkan bahwa terdapat pengaruh positif dan signifikan kepuasan mahasiswa terhadap loyalitas mahasiswa.

\section{KESIMPULAN}

Dari hasil penelitian mengenai hubungan kualitas pelayanan dan kepuasan mahasiswa terhadap loyalitas mahasiswa maka dapat disimpulkan sebagai berikut.

1. Mahasiswa merasa setuju tentang kualitas pelayanan, kepuasan mahasiswa, dan loyalitas mahasiswa di Akademi Farmasi Surabaya.

2. Hasil uji validitas pada semua item pernyataan adalah valid dan hasil uji reliabilitas adalah reliabel.

3. Variabel kualitas pelayanan dan kepuasan mahasiswa berpengaruh positif dan signifikan terhadap loyalitas mahasiswa. 


\section{REFORMASI}

ISSN 2088-7469 (Paper) ISSN 2407-6864 (Online)

Volume 8 Nomor 2 (2018)

\section{SARAN}

Pada penelitian selanjutnya agar menambahkan variabel independen (X) karena untuk meningkatkan nilai R-square. Sedangkan untuk institusi perlu lebih memperhatikan kualitas pelayanan dimana beberapa jawaban mahasiswa masuk ke kategori kurang setuju.

Keterbatasan yang ditemukan dalam penelitian ini dapat menjadi sumber ide bagi penelitian yang akan datang, misalnya penelitian terhadap Universitas, Sekolah Tinggi, Akademi sebaiknya juga dilakukan pada pelayanan Dosen, BAAK, BAUK, dan Pejabat Struktural di Perguruan Tinggi Swasta lainnya. Selain itu dalam penelitian yang akan datang, sebaiknya juga memasukkan variabel lain yang dipandang dapat mempengaruhi kepuasan dan loyalitas mahasiswa, seperti faktor rasio dosen dan mahasiswa, faktor sumber daya manusia, manajemen perguruan tinggi, sarana prasarana belajar mengajar, serta kompetensi dan apresiasi lulusan pada proses edukatif dan lain-lain sebagainya.

\section{DAFTARPUSTAKA}

Alifuddin, B. 2012. Pemasaran Stratejik Jasa Pendidikan. Bandung: Alfabeta.

Bergin, S. 1997. Communication is the Key to Customer Success. California: Transportation and Distribution.

Gold, E. 2001. Customer Service: A Key Unifying for Today's Campus. Journal of Netresults, National Association of Student Personnel Administration, 5(4), 154 173.

Muafi dan Yuni Siswanti, 2007, Anteseden Ekuitas Merek Perguruan Tinggi: SEM dengan Pendekatan Two Step, Manajemen Usahawan Indonesia, no. 03, TH XXXVI, Maret, 2007, p. $27-34$.

Panca, W 2012. Pengaruh Pembelajaran Dan Kualitas Pelayanan Terhadap Kepuasan Dan Loyalitas Mahasiswa Universitas Muria Kudus,Jurnal Dinamika Ekonomi \& Bisnis.Vol. 9 No. 2 Oktober 2012.

Tjiptono, F. 2014. Strategi Pemasaran, Yogyakarta: Edisi II. Andi Ofset.

Undang-Undang Nomor 20 tahun 2003. Sistem Pendidikan Nasional. Jakarta: BP. Cipta Jaya. 